\title{
The Influence of Enzymatic Hydrolysis of Whey Proteins on the Properties of Gelatin-Whey Composite Hydrogels
}

\author{
Violeta Popescu ${ }^{1}{ }^{\circ}$, Andreia Molea ${ }^{2}$, Marioara Moldovan ${ }^{3}{ }^{\circledR}$, Pompilia Mioara Lopes ${ }^{1}$, \\ Amalia Mazilu Moldovan ${ }^{1}$ and George Liviu Popescu ${ }^{1,2, *}$ \\ 1 Physics and Chemistry Department, Technical University of Cluj-Napoca, 28 Memorandumului Str., \\ 400114 Cluj-Napoca, Romania; violeta.popescu@chem.utcluj.ro (V.P.); Mioara.Lopes@im.utcluj.ro (P.M.L.); \\ amalia.mazilu@gmail.com (A.M.M.) \\ 2 Automotive Engineering and Transports Department, Technical University of Cluj-Napoca, \\ 28 Memorandumului Str., 400114 Cluj-Napoca, Romania; Andreia.MOLEA@auto.utcluj.ro \\ 3 Institute of Chemistry Raluca Ripan, Babes-Bolyai University, 30 Fantanele Str., \\ 400294 Cluj-Napoca, Romania; marioara.moldovan@ubbcluj.ro \\ * Correspondence: georgepopescu60@gmail.com; Tel.: +40-743174196
}

Citation: Popescu, V.; Molea, A.; Moldovan, M.; Lopes, P.M.; Mazilu Moldovan, A.; Popescu, G.L. The Influence of Enzymatic Hydrolysis of Whey Proteins on the Properties of Gelatin-Whey Composite Hydrogels. Materials 2021, 14, 3507. https:// doi.org/10.3390/ma14133507

Academic Editor: Jordi Marti

Received: 28 April 2021

Accepted: 16 June 2021

Published: 23 June 2021

Publisher's Note: MDPI stays neutral with regard to jurisdictional claims in published maps and institutional affiliations.

Copyright: (c) 2021 by the authors. Licensee MDPI, Basel, Switzerland. This article is an open access article distributed under the terms and conditions of the Creative Commons Attribution (CC BY) license (https:/ / creativecommons.org/licenses/by/ $4.0 /)$.

\begin{abstract}
Amino-acids, peptides, and protein hydrolysates, together with their coordinating compounds, have various applications as fertilizers, nutritional supplements, additives, fillers, or active principles to produce hydrogels with therapeutic properties. Hydrogel-based patches can be adapted for drug, protein, or peptide delivery, and tissue healing and regeneration. These materials have the advantage of copying the contour of the wound surface, ensuring oxygenation, hydration, and at the same time protecting the surface from bacterial invasion. The aim of this paper is to describe the production of a new type of hydrogel based on whey protein isolates (WPI), whey protein hydrolysates (WPH), and gelatin. The hydrogels were obtained by utilizing a microwave-assisted method using gelatin, glycerol, WPI or WPH, copper sulfate, and water. WPH was obtained by enzymatic hydrolysis of whey protein isolates in the presence of bromelain. The hydrogel films obtained have been characterized by FT-IR and UV-VIS spectroscopy. The swelling degree and swelling kinetics have also been determined.
\end{abstract}

Keywords: whey proteins isolate; whey proteins hydrolysates; hydrogels; swelling degree; swelling kinetics

\section{Introduction}

Amino-acids, peptides, and protein hydrolysates together with their coordinating compounds have various applications as fertilizers, nutritional supplements, additives, fillers, or active principles to produce hydrogels with therapeutic properties [1,2].

Whey is the soluble fraction of milk, rich in proteins, minerals, and lactose that are separated from casein during the manufacture of cheese or casein.

Whey has been considered for a long time as a by-product of cheese and curd manufacturing. In the last years, whey proteins and their hydrolyzed products have proved to have a large scale of bioactive properties.

Whey can be a very useful and valuable solution among protein raw materials for amino-acid/peptide production, due to its low cost and availability, high nutritional value, low bitterness and low antigenicity; whey being the major by-product of cheese manufacturing, representing up to $20 \%$ of total milk proteins $[3,4]$.

Enzymatic hydrolysis of whey can be used for improving the functional, nutritional, and immunological properties of proteins, reducing the allergenicity and antigenicity of the proteins.

Bioactive components of the hydrolyzed products of whey cover a wide spectrum of compounds with anti-carcinogenic, antifungal, antihypertensive, antimicrobial [5], an- 
tioxidative [6,7], anti-proliferative, anti-thrombotic, antiulcerogenic [8], antiviral, and immunomodulatory [9] properties, while also having prebiotic activity [10-12].

Hydrogel-based patches can be adapted for drug, protein, or peptide delivery, and tissue healing and regeneration [13]. These materials have the advantage of copying the contour of the wound surface, ensuring oxygenation, hydration, and at the same time protecting the surface from bacterial invasion.

The biocompatibility of whey hydrogels and the exposure of the hydrophobic groups that can bind different types of drugs allows them to be used as drug delivery systems [14]

Gels or soft hydrogels obtained from proteins, peptides, or other natural compounds can also be used for tooth whitening and remineralization $[15,16]$.

The aggregation of proteins and the properties of the gels, hydrogels, or microspheres based on whey can be influenced by other components such as k-carrageenan [17-21], alginate [22-27], gellan [28], chitosan [29], xanthan, pectine [27], carbonanotubes, and carbon nano-onions [30], most of which also have crosslinking effects.

Whey protein isolates and whey protein concentrates can be used as renewable raw materials for obtaining polymer sheets by free radical polymerization with poly(ethylene glycol) methyl ether methacrylate (PEGMA) [31] or tissue adhesive using glutaraldehyde [32].

Whey protein hydrogels can be obtained by ionotropically crosslinking with $\mathrm{CaCl}_{2}$ [29,33-36], $\mathrm{MnCl}_{2}$ and $\mathrm{ZnCl}_{2}$ [35], $\mathrm{NaCl}[28,36], \mathrm{Fe}^{2+}[37,38]$ and $\mathrm{Mg}^{2+}$ [39] or chemically crosslinking with citric acid [40,41], D-(+)-Gluconic acid D-lactone (GDL) [42], isomaltooligosaccharide [43], and tanninic acid [14].

In order to improve the mechanical properties of whey protein hydrogels, B. A. Aderibigbe and S. Ndwabu obtained whey protein isolate-graft-carbopol-polyacrylamidebased hydrogel composites [44].

Although there are numerous studies on obtaining hydrogels based on gelatin [45-48] with application related to wound dressing and hydrogels based on whey proteins with other applications $[49,50]$, the studies related to the hydrogels based on gelatin and whey proteins are quite rare, but the obtaining and characterization of diverse, composites or films has been studied [51-55].

Strong interactions between whey and gelatin determined important changes in the mechanical, thermal, and gelling properties of whey protein-gelatin composite films or gels [54-58].

The addition of small amounts of gelatin to WPI improves the strength and stability of gels, indicating synergistic interaction between whey and gelatin, in the presence or the absence of a crosslinking agent such as transglutaminase, influencing the rheological and thermal properties of materials $[54,59,60]$ and water holding capacity [56]. The introduction of gelatin in composite laminated multilayered films containing WPI and sodium alginate increased the elasticity of the films [57]. The interaction between whey and gelatin depends on the $\mathrm{pH}$ and polymer ratio [58], depending also on the treatments applied to whey, for example, the polymerization of whey increased the interactions between the two proteins [59].

On the other hand, the addition of whey proteins conducted to the stabilization of gelatin and carboxymethylcellulose water-in-water emulsion [60] or aerated gelatin gels [61].

Whey protein isolates and porcine gelatin have been also successfully tested for incorporation of quinoa oil using Tween 20 as surfactant, making the oil more dispersible in water, and potentializing the antioxidant activity for application in a food matrix [62].

Although there are many studies related to the obtaining and characterization of gels or films, we have identified only one article that addresses the obtaining of a whey and gelatin hydrogel. This study involved an investigation on a multicomponent organic-inorganic WPI/gelatin/calcium phosphate hydrogel composites for bone tissue engineering [63]. 
We introduced copper ions into the hydrogel matrix because copper ions, its derivatives such as amino-acid complexes [64-66], copper nanoparticles [67,68], and nano-copperzinc alloy (nCuZn) [69] have both functional and antibacterial properties.

The aim of this research is to produce a new type of hydrogel based on whey protein isolates or whey protein hydrolysates and gelatin crosslinked with copper ions. As far as we know, it is the first study that approaches hydrogels based on WPI or WPI hydrolysates and gelatin, crosslinked with copper ions.

\section{Materials and Methods}

\subsection{Materials}

Whey Protein Izolate (WPI) ISOLAC produced by Carbery Group and distributed by S.C. Way Better Nutrition from Cluj-Napoca has been used for the obtaining of whey protein hydrolysates using Bromelain from pineapple stem from BioChemica. Details regarding WPI main characteristics are presented in our paper [70]. A solution of $0.45 \mathrm{M} / \mathrm{L} \mathrm{NaOH}$ (Sigma-Aldrich, Taufkirchen, Germany) has been used for maintaining the $\mathrm{pH}$ constant during the enzymatic hydrolysis applying $\mathrm{pH}$-stat method [71]. Gelatin 270 bloom type A (Gelita, Cotia, São Paulo, Brazil), glycerol (Sigma-Aldrich, Taufkirchen, Germany), $\mathrm{CuSO}_{4}$ * $5 \mathrm{H}_{2} \mathrm{O}$ (Sigma-Aldrich, Taufkirchen, Germany) have been used for hydrogels preparation.

\subsection{The Production of Whey Hydrolysates}

Whey Protein Hydrolysates (WPH) obtained by enzymatic hydrolysis of solutions of $5 \%$ whey protein isolate (WPI), in the presence of $0.05 \%$ bromelain have been used to produce the hydrogels. For hydrolysis $200 \mathrm{~mL}$ solutions of WPI have been prepared using distilled water. For a better dispersion of the whey powder the solution was sonicated for $15 \mathrm{~min}$ and preheated to $60^{\circ} \mathrm{C}$ and the $\mathrm{pH}$ was adjusted to 8 . The hydrolysis took place for $360 \mathrm{~min}$ at constant $\mathrm{pH}$ with bromelain and the degree of hydrolysis determined based on the consumption of $\mathrm{NaOH}$ solutions with known concentration [71,72] was $3.92 \%$.

\subsection{Preparation of Hydrogels}

Gelatin-based hydrogels were obtained by microwave assisted method using gelatin, glycerol, whey hydrolysates or WPI and $\mathrm{CuSO}_{4} * 5 \mathrm{H}_{2} \mathrm{O}$. The gelatin was mixed with glycerol and water, then the sample was kept at room temperature for $10 \mathrm{~min}$, followed by the addition of WPI or WPH solutions. The mixtures were subjected to irradiation in a household microwave system at $480 \mathrm{~W}$ for $25 \mathrm{~s}$ until homogenous and clear solutions were obtained.

To determine the influence of the cross-linking agent, hydrogels with different concentration of $\mathrm{Cu}^{2+}$ were synthesized from $0.5 \mathrm{~g}$ gelatin, $0.4 \mathrm{~g}$ glycerol, $4 \mathrm{~mL}$ hydrolysates or $5 \%$ WPI solutions, $2 \mathrm{~mL}$ water adding various quantities of $30 \% \mathrm{CuSO}_{4} \times 5 \mathrm{H}_{2} \mathrm{O}$ solutions. The samples were poured in Petri dishes and dried at room temperature for 2 days. For comparison, control hydrogel samples were prepared using $5 \%$ whey protein isolate solutions.

Table 1 presents the conditions for the obtaining of gelatin-whey hydrogels.

Table 1. The conditions for the obtaining of gelatin-whey hydrogels.

\begin{tabular}{|c|c|c|c|c|}
\hline $\begin{array}{l}\text { Sample } \\
\text { Name }\end{array}$ & $\begin{array}{l}\mathrm{Grams} \mathrm{CuSO}_{4} \\
* 5 \mathrm{H}_{2} \mathrm{O} / \mathrm{Sample}\end{array}$ & $\begin{array}{c}\text { Concentration } \\
\mathrm{CuSO}_{4} * 5 \mathrm{H}_{2} \mathrm{O}[\%]\end{array}$ & Sample Preparation & $\begin{array}{c}\text { Average Films } \\
\text { Thickness } \\
{[\mu \mathrm{m}]}\end{array}$ \\
\hline $\mathrm{H}$ & 0 & 0.0 & $\begin{array}{c}0.5 \text { g gelatin }+0.4 \text { g glycerol }+ \\
4 \text { mL hydrolysate }+2 \mathrm{~mL} \text { water }\end{array}$ & 231 \\
\hline H WPI & 0 & 0.0 & $\begin{array}{l}0.5 \text { g gelatin }+0.4 \text { g glycerol }+ \\
4 \text { mL WPI } 5 \%+2 \text { mL water }\end{array}$ & - \\
\hline Н 0.036 & 0.036 & 0.5 & 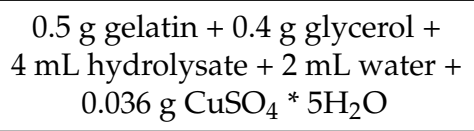 & 266 \\
\hline
\end{tabular}


Table 1. Cont.

\begin{tabular}{|c|c|c|c|c|}
\hline $\begin{array}{l}\text { Sample } \\
\text { Name }\end{array}$ & $\begin{array}{l}\mathrm{Grams} \mathrm{CuSO}_{4} \\
* 5 \mathrm{H}_{2} \mathrm{O} / \mathrm{Sample}\end{array}$ & $\begin{array}{c}\text { Concentration }{ }^{1} \\
\mathrm{CuSO}_{4} * 5 \mathrm{H}_{2} \mathrm{O}[\%]\end{array}$ & Sample Preparation & $\begin{array}{c}\text { Average Films } \\
\text { Thickness } \\
{[\mu \mathrm{m}]}\end{array}$ \\
\hline WPI 0.036 & 0.036 & 0.5 & $\begin{array}{l}0.5 \text { g gelatin }+0.4 \text { g glycerol }+ \\
4 \mathrm{~mL} \mathrm{WPI} \% \%+2 \mathrm{~mL} \text { water }+ \\
0.036 \mathrm{~g} \mathrm{CuSO}_{4} * 5 \mathrm{H}_{2} \mathrm{O}\end{array}$ & 262 \\
\hline Н 0.06 & 0.06 & 0.9 & $\begin{array}{c}0.5 \text { g gelatin }+0.4 \text { g glycerol }+ \\
4 \text { mL hydrolysate }+2 \mathrm{~mL} \text { water }+ \\
0.06 \mathrm{~g} \mathrm{CuSO}_{4} * 5 \mathrm{H}_{2} \mathrm{O}\end{array}$ & 286 \\
\hline WPI 0.06 & 0.06 & 0.9 & $\begin{array}{c}0.5 \text { g gelatin }+0.4 \text { g glycerol }+ \\
4 \mathrm{~mL} \mathrm{WPI} \% \%+2 \mathrm{~mL} \text { water }+ \\
0.06 \mathrm{~g} \mathrm{CuSO}_{4} * 5 \mathrm{H}_{2} \mathrm{O}\end{array}$ & 290 \\
\hline Н 0.072 & 0.072 & 1 & $\begin{array}{c}0.5 \text { g gelatin }+0.4 \text { g glycerol }+ \\
4 \mathrm{~mL} \text { hydrolysate }+2 \mathrm{~mL} \text { water }+ \\
0.072 \mathrm{gCuSO}_{4} * 5 \mathrm{H}_{2} \mathrm{O}\end{array}$ & 271 \\
\hline WPI 0.072 & 0.072 & 1 & $\begin{array}{l}0.5 \text { g gelatin }+0.4 \text { g glycerol }+ \\
4 \mathrm{~mL} \mathrm{WPI} \%+2 \mathrm{~mL} \text { water }+ \\
0.072 \mathrm{gCuSO}_{4} * 5 \mathrm{H}_{2} \mathrm{O}\end{array}$ & 269 \\
\hline Н 0.12 & 0.12 & 1.7 & $\begin{array}{c}0.5 \text { g gelatin }+0.4 \text { g glycerol }+ \\
4 \text { mL hydrolysate } 2 \mathrm{~mL} \text { water }+ \\
0.12 \mathrm{~g} \mathrm{CuSO}_{4} * 5 \mathrm{H}_{2} \mathrm{O}\end{array}$ & 269 \\
\hline Н 0.24 & 0.24 & 3 & $\begin{array}{c}0.5 \text { g gelatin }+0.4 \text { g glycerol }+ \\
4 \mathrm{~mL} \text { hydrolysate } 2 \mathrm{~mL} \text { water }+ \\
0.24 \mathrm{~g} \mathrm{CuSO}_{4} * 5 \mathrm{H}_{2} \mathrm{O}\end{array}$ & 278 \\
\hline
\end{tabular}

${ }^{1}$ Concentration $\mathrm{CuSO}_{4} * 5 \mathrm{H}_{2} \mathrm{O}[\%]$ reported to sample without water.

\subsection{Optical Properties of the Hydrogels}

Optical properties in visible and near infrared region of spectra (between 400 and $1000 \mathrm{~nm}$ ) of the hydrogel films were determined using a double bean Perkin Elmer Lambda 25 UV/Vis Spectrophotometer (PerkinElmer, Waltham, MA, USA) before taking the samples from the Petri dishes, using for blank two clean empty Petri dishes.

\subsection{Swelling Tests}

For swelling tests, a method adapted from [73] has been applied. Tea bags were immersed in the swelling medium (distilled water) for $24 \mathrm{~h}$. The empty bags were patted with paper towels to remove excess water and weighted $\left(W_{1}\right)$. Around $0.05 \mathrm{~g}$ of samples were weighted $\left(W_{2}\right)$, placed into the tea bag and sealed. The samples from tea bags were immersed in swelling media, weighted at predetermined times $\left(W_{3}\right)$ until the swelling equilibrium has been reached. The swelling degree [ $g$ water/g hydrogel] has been calculated with the equation:

$$
S W=\frac{W_{3}-W_{2}-W_{1}}{W_{2}}[\mathrm{~g} / \mathrm{g}]
$$

If SW is expressed as percent, the following equation must be used:

$$
S W \%=\frac{W_{3}-W_{2}-W_{1}}{W_{2}} \cdot 100[\%]
$$

\subsection{Thickness of the Films}

The thickness of the films has been measured with a TROTEC BB25 coating thickness meter. For each sample, the thickness has been measured in 4 points and the average value has been calculated. 


\section{Results and Discussions}

\subsection{FTIR Analysis of WPI, WPH and Gelatin-Whey Hydrogels}

The FT-IR spectra of WPI, WPH and hydrogels have been normalized for Amide I band (wavenumbers from 1800 to $1600 \mathrm{~cm}^{-1}$ ), to make a better comparison between them for evaluation of the changes into the protein's structures.

FT-IR spectra of whey protein isolates and whey protein hydrolysates are presented in Figure 1.

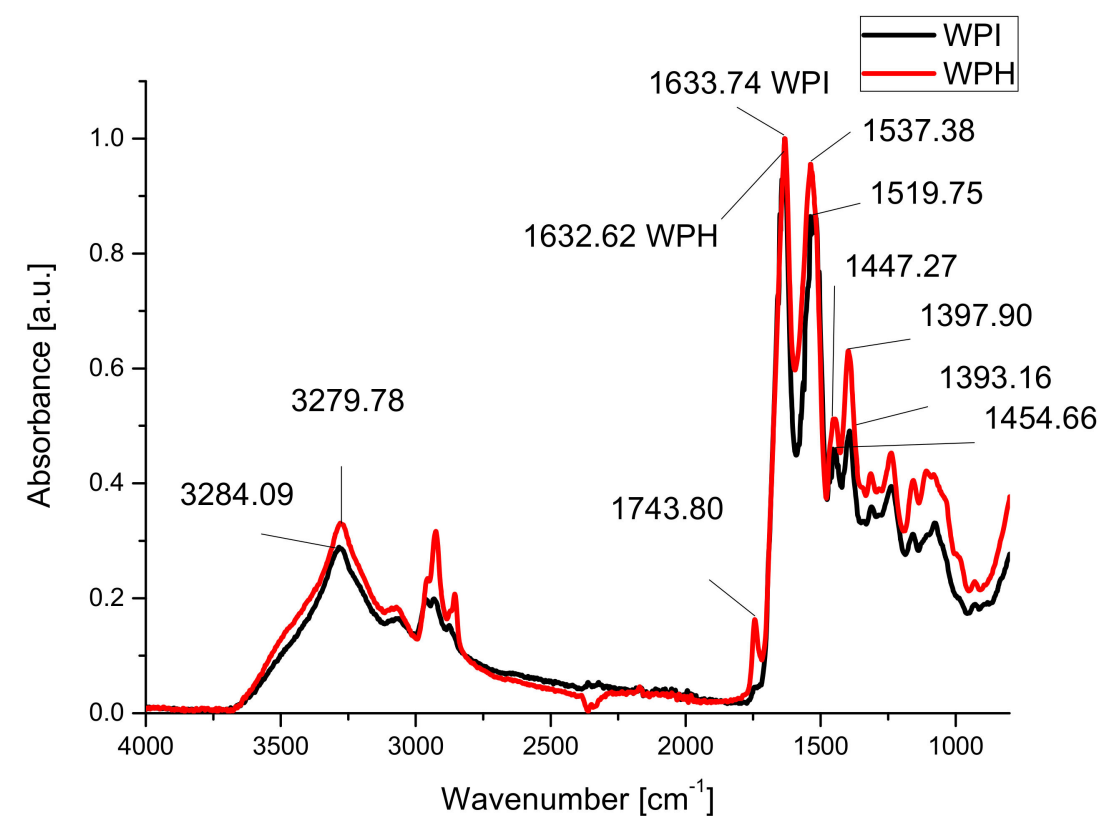

Figure 1. FTIR spectra of whey protein isolate (WPI) and whey protein hydrolysate (WPH).

FT-IR spectra showed an increase in the intensities of absorption band centered around $1536 \mathrm{~cm}^{-1}$ for the hydrolyzed sample compared to WPI due to the formation of primary amines following hydrolysis [74]. More than that, the band centered around $1400 \mathrm{~cm}^{-1}$ (related to terminal-COOH group) (amide III [75]) also increased compared to the band from $1632 \mathrm{~cm}^{-1}$ (amide I). A new absorption band appeared at around $1744 \mathrm{~cm}^{-1}$ due to the formation of new carboxylic groups following enzymatic hydrolysis. Compared to amide I absorption band one can see increased of the intensity and area of the vibration band (3640-3097 $\mathrm{cm}^{-1}$ ) due to the hydrogen bonds in the case of hydrolyzed sample.

In the case of hydrogels, FTIR analyses were carried out to observe changes into the protein's structures following the formation of hydrogels in different conditions. The absorption bands amide I (centered at $1633 \mathrm{~cm}^{-1}$ ), amide II (around $1537 \mathrm{~cm}^{-1}$ ) and amide III (between 1400 and $1200 \mathrm{~cm}^{-1}$ ) [41,76] have been analyzed for studying changes into the secondary structure of proteins, while the absorption band from $1034 \mathrm{~cm}^{-1}$ due to the stretching vibration of hydroxyl groups of glycerol was studied in order to evaluate the interactions with the plasticizer $[35,43]$.

Amide I absorption band shifts to smaller wavenumbers, $1632.62 \mathrm{~cm}^{-1}$ compared to $1633.74 \mathrm{~cm}^{-1}$ for sample WPH due to the disruption of $\mathrm{C}=\mathrm{O} \cdots \mathrm{H}-\mathrm{N}$ hydrogen bonds in whey following hydrolysis, and can be associated with the decreasing of the $\alpha$ helix structures in the proteins $[77,78]$.

The influence of copper concentration of the FT-IR spectra of hydrogels is presented in Figure 2. 


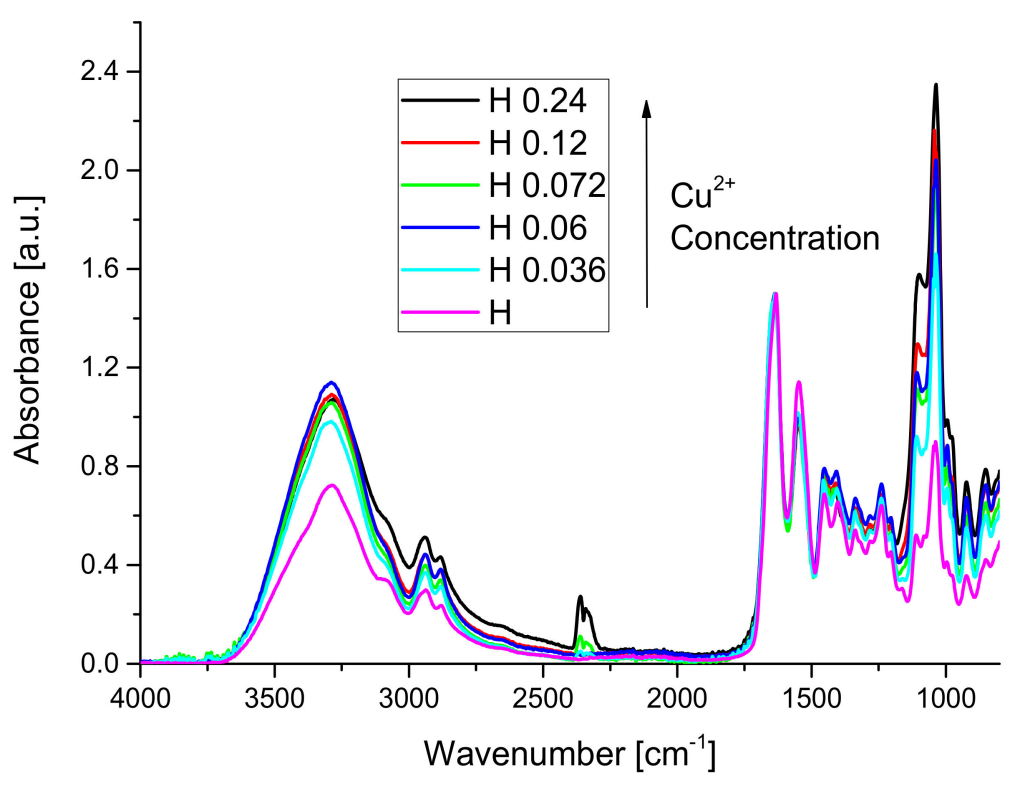

Figure 2. The influence of copper concentration on the FT-IR spectra of hydrogels.

Comparing the spectrum of WPH with the spectra of hydrogels, one can observe that the absorption band from $1744 \mathrm{~cm}^{-1}$ disappeared from the spectra of hydrogels because copper interacted with - $\mathrm{COOH}$ groups of whey forming ionic crosslinking bridges between the protein chains. No new absorption bands appeared in the spectra of hydrogels because no new covalent bonds were formed. Important changes in the amide A, amide II, amide III absorption bands have been observed. Amide A band, which can be attributed to $\mathrm{NH}$ stretching coupled with hydrogen bonds, suffered an important increase due to the presence of the copper sulfate in the sample. The peak situated around $1033 \mathrm{~cm}^{-1}$ is related to the interactions arising between the plasticizer $(\mathrm{OH}$ group of glycerol) and film structure [41,78].

The influence of using hydrolyzed whey protein on FT-IR spectra is presented in Figure 3.

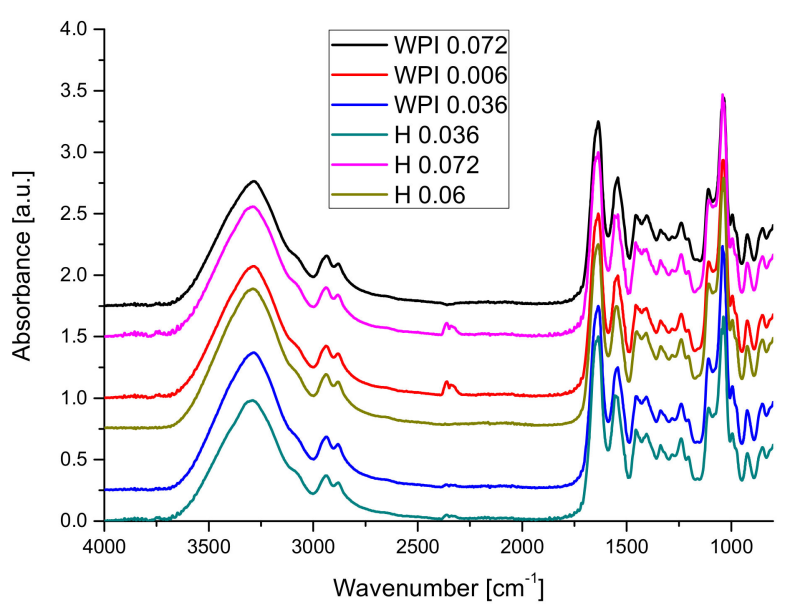

Figure 3. The influence of the WPH on of the FT-IR spectra of hydrogels.

Figure 3 illustrates that the use of hydrolyzed whey protein leads to an increase in intensity of the hydrogen bond vibrations (samples 0.06 and 0.072) leading also to small changes in amide I bands and important changes in amide II and amide III bands and the band from $1033 \mathrm{~cm}^{-1}$. Changes in the amide III vibrations band may be related to changes in the secondary structure of proteins chains following the addition of copper $[79,80]$. 
One can conclude that the hydrolysis process exposed more functional groups able to form hydrogen bonds in the hydrogels and to influence the interaction between the protein's chains and plasticizer.

The increasing number of hydrogen bonds will lead to increasing of stability of hydrogels.

\subsection{Optical Properties of the Hydrogels}

Proteins from gelatin and whey and their hydrogels absorb small wavelengths in the UV region of the spectrum, presenting an absorption peak at $280 \mathrm{~nm}$ [81] and low absorption in visible and near infrared. Globular proteins from whey and gelatin absorb wavelengths from UV region of the spectrum in the range 190-220 $\mathrm{nm}$ due to peptide bonds and amino-acids and around $280 \mathrm{~nm}$ due to absorption of tyrosine and tryptophan [81].

For our sample, the optical properties in the wavelengths of the visible range (Figure 4) were of main interest because of the intended application of the hydrogels as wound healing dresses or drug delivery transdermal patches.

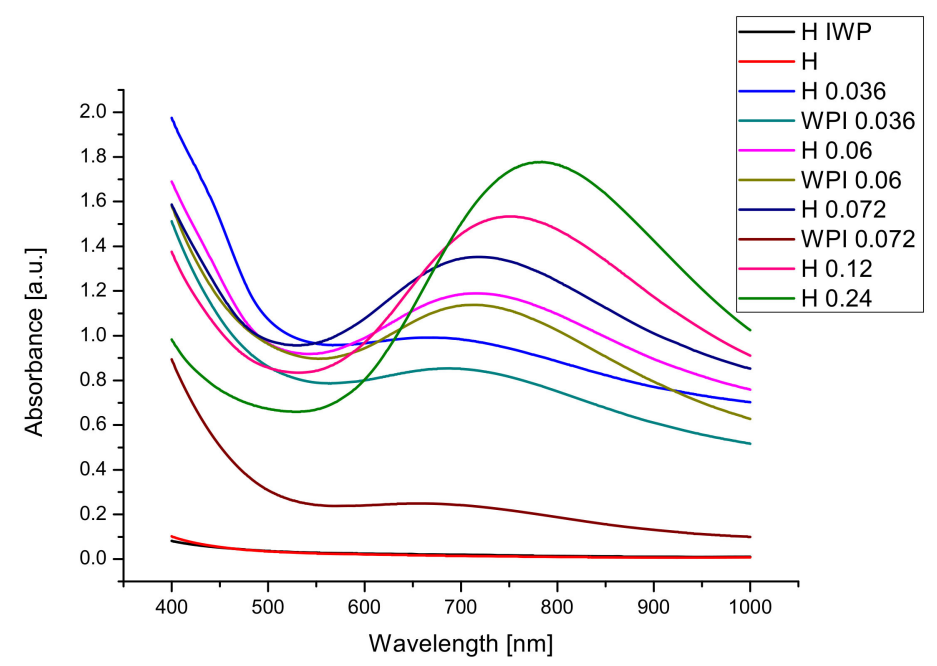

Figure 4. Optical properties of hydrogel films.

The samples with the smallest absorption are the samples obtained from the gelatin and whey protein hydrolysates without $\mathrm{Cu}$ (II) crosslinking agent.

Using copper sulphate for obtaining hydrogels leads to the formation of samples with higher absorbance, in all cases. The high values of absorbance for films containing copper can be explained by the presence of the copper-based crosslinking agent. For facilitating the study of our hydrogels, we prepared thick samples, but for clinical application thinner films will be made to allow visual observation of the treated area. By increasing the concentration of $\mathrm{Cu}^{2+}$ films with smaller transmittance (higher absorbance) have been obtained. The use of hydrolyzed whey proteins led to an increase in the absorbance of the film, due to changes in the structure of the hydrogels.

\subsection{Swelling Tests}

The results obtained for swelling degree are presented in Figure 5.

The swelling process took place with a high rate the first 50-100 $\mathrm{min}$. The presence of copper ions as crosslinking agent and the hydrogen bonds formed between the proteins chains involving both functional groups from proteins and plasticizer (glycerol) stabilized the hydrogel that continue to swell, at a smaller rate when the materials were kept in water for $120 \mathrm{~h}$. The turbidity of swelling environment increased following the swelling experiment suggesting that a part of hydrogel matrix begins to disintegrate, phenomenon worth investigating into the future. The decreasing of the swelling rate revealed changes in the swelling dynamics. 


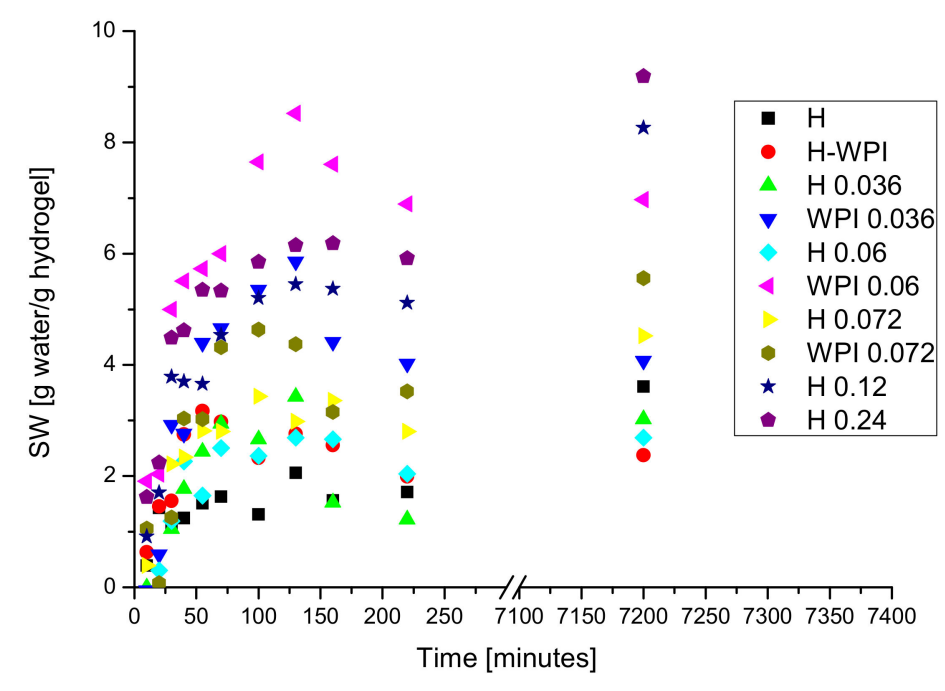

Figure 5. The variation of the swelling degree as a function of swelling time.

Swelling kinetics in water of hydrogels can be evaluated with the relation:

$$
\frac{W_{t}}{W_{e}}=k_{F} \cdot t^{n_{F}}
$$

where: $W_{t}$ is the weight of hydrogel at time $t$, while $W_{e}$ is the weight of hydrogel at equilibrium. $K_{F}$ is diffusion constant of water into the hydrogel matrix, and $\mathrm{n}$ is an exponent of the diffusion process. If $n_{F}=0.5$, the diffusion process takes place based on a Fickian perfect model, when the rate of the relaxation of the polymer is higher than the rate of water diffusion. The value of $n=1$ indicated a non-Fickian diffusion process when the diffusion rate of water is higher than the rate of relaxation of polymeric chains. If $0.5<n<1$ relaxation rate of the network is comparable with the rate of water diffusion. The exponents of the swelling process for hydrogels are calculated from the slope of the chart $\log \left(\frac{W_{t}}{W_{e}}\right)=f(\log t)$ for swellings smaller than $60 \%[42,82,83]$. For our samples the correlation coefficients for the plots $\log \left(\frac{W_{t}}{W_{e}}\right)=f(\log t)$, for all swelling time (plot not presented) have small values revealing that the whole process does not follow a Fickian model. However, in the first 30 to 55 min of swelling, depending on the sample, the swelling follows a Fickian model, and the values of constant $n_{F}$ are between 0.5 and 1 for some samples, suggesting that relaxation rate of the network is comparable with the rate of water diffusion, or higher than 1 for other samples suggesting non-Fickian kinetics. The values obtained for $k_{F}, n_{F}$, and $\mathrm{R}_{\mathrm{F}}{ }^{2}$ from the plot $\log \left(\frac{W_{t}}{W_{e}}\right)=f(\log t)$ are presented in Table 2. There are no clear correlations between the composition of the hydrogels and the values of constants obtained from the Fickian model.

Table 2. The variation of swelling degree (experimental and calculated) and rate constant.

\begin{tabular}{ccccccccccc}
\hline Sample & H & H-WPI & H 0.036 & WPI 0.036 & H 0.06 & WPI 0.06 & H 0.072 & WPI 0.072 & H 0.12 & H 0.24 \\
\hline $\mathrm{n}_{\mathrm{F}}$ & 1.07 & 1.18 & 0.85 & 1.53 & 1.39 & 0.79 & 1.31 & 0.64 & 1.11 & 0.79 \\
$\mathrm{k}_{\mathrm{F}}$ & 1.97 & 1.77 & 1.66 & 2.66 & 2.48 & 1.33 & 2.28 & 1.40 & 2.06 & 1.50 \\
$\mathrm{R}_{\mathrm{F}}{ }^{2}$ & 0.7392 & 0.9997 & 0.9454 & 0.8894 & 0.9094 & 0.9704 & 0.8168 & 0.7137 & 0.9431 & 0.9326 \\
SW calculated & 3.66 & 2.90 & 3.05 & 4.08 & 2.70 & 6.98 & 5.18 & 5.60 & 8.33 & 9.99 \\
SW experimental & 3.61 & 2.55 & 3.03 & 4.70 & 2.69 & 6.97 & 4.70 & 5.56 & 8.26 & 9.19 \\
$\mathrm{k}[1 / \mathrm{h}]$ & 0.16 & 4.92 & 0.06 & 2.22 & 0.89 & 1.19 & 0.25 & 0.19 & 0.11 & 0.10 \\
$\mathrm{R}^{2}$ & 0.9987 & 0.9999 & 0.9975 & 0.9996 & 0.9994 & 0.9999 & 0.9988 & 0.9995 & 0.9997 & 0.9998 \\
\hline
\end{tabular}

Similar behavior has been reported for hydrogels based on whey protein concentrates loaded with caffeine [82]. They concluded that swelling curves deviate from the classical Fickian model because the swelling process is not a passive diffusion involving the pen- 
etration of solvent into the pores of the hydrogels network, but includes a simultaneous relaxation of the protein's chains conducting to a significant increase in volume.

Another Fickian equation that described the diffusion of swelling medium molecules through hydrogel taking into consideration the swelling degree $(S W)$, diffusion constant $(k)$ of water into the hydrogel matrix, diffusion exponent $(n)$ can be used for kinetic studies:

$$
S W=k \cdot t^{n}
$$

If there is a linear relationship between $S W_{t}$ and $t^{1 / 2}$, the process follows a Fickian model.

The fitting curves $S W_{t}=f\left(t^{\frac{1}{2}}\right)$ for the prepared hydrogels (not presented) presents no linearity, demonstrating once again that the process does not follow a Fickian model.

If global the process follows second order kinetics, the following equation describes the process [83]:

$$
\frac{d S W}{d t}=k \cdot\left(S W_{e}-S W_{t}\right)^{2}
$$

where: $\frac{d S W_{t}}{d t}$ is the swelling rate, $k$ is the rate constant $(1 / \mathrm{h})$, and $S W_{e}$ is the value of the swelling at equilibrium (maximum swelling degree).

By integration and rearrangement of the terms, Schott's equation results [73]:

$$
\frac{\mathrm{t}}{\mathrm{SW}}=\frac{1}{\mathrm{k} \cdot \mathrm{SW}_{\mathrm{e}}^{2}}+\frac{\mathrm{t}}{\mathrm{SW}}
$$

By plotting $\frac{t}{S W}$ against $\mathrm{t}$ a straight line with the slope of $\frac{1}{S W_{e}}$ and the intercept of $\frac{1}{k} \cdot S W_{e}^{2}$ will be obtained. The value of $S W_{e}$ will be calculated from the slope and the value of diffusion constant $\mathrm{k}$ from the intercept or the Schott's equation:

$$
\begin{gathered}
\mathrm{SW}=\frac{1}{\text { slope }} \\
\mathrm{k}=\frac{1}{\text { Intercept } \cdot \mathrm{SW}_{\mathrm{e}}^{2}}
\end{gathered}
$$

The plot of $\frac{t}{S W}$ against $t$ for samples $\mathrm{H}$ and WPI are presented in Figure 6a, while for samples containing copper in Figure 6b. In all cases, a straight line was obtained with high values for correlation coefficients.

Sundaram Gunasekaran et al. showed that whey protein hydrogels are $\mathrm{pH}$ sensitive and the swelling kinetics depend on $\mathrm{pH}[44,82]$. They concluded that raising the $\mathrm{pH}$ of the swelling medium increases the swelling rate.

The dependence of calculated swelling degree, experimental value of swelling degree, and rate constant as a function of copper concentration is presented in Table 2.

One can see that for samples that contain more than $0.87 \% \mathrm{CuSO}_{4} * 5 \mathrm{H}_{2} \mathrm{O}$, both calculated and experimental values for swelling degree increased with increasing copper concentration. Increasing the number of crosslinking bridges due to ionic bonds determined an increase in the stability of hydrogels. For almost all samples, the value of calculated maximum swelling degree is a little higher than the value of the experimental one, due to the dissolution of the sample into the swelling environment when the SW was high.

Rate constant k, decreased with increasing concentration of copper (II) ions due to the increasing of crosslinking process by $\mathrm{Cu}^{2+}$ bridges.

For all samples, the swelling degree decreased when WPH have been used instead of WPI demonstrating the importance of the new functional groups formed during enzymatic hydrolysis.

The value of the rate constant decreased with the increase in copper concentration. The highest rate constant value has been obtained in the case of the sample made from WPI without copper. 
The pictures of the samples after a week in aqueous solution (Figure 7) revealed that hydrogels containing WPI were very soft and subsequently very difficult to manipulate, looking more like gels, while the samples containing hydrolyzed whey proteins are much more stable. Samples with no copper could not be removed from tea bags with a gel-like structure. In the case of sample H 0.24 with a swelling degree of $10 \mathrm{~g}$ water $/ \mathrm{g}$, hydrogel the same gel consistency has been observed. One can conclude that crosslinking both trough ionic and hydrogen bonds stabilized the hydrogels, and the use of partially hydrolyzed whey proteins has a good influence on hydrogel stability.

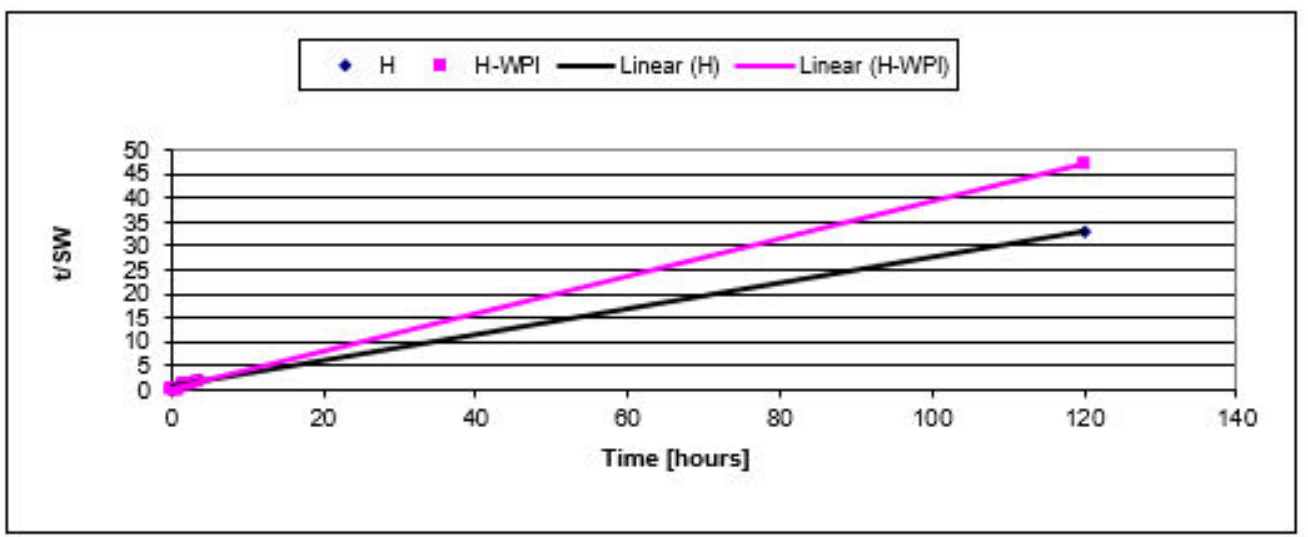

(a)

\begin{tabular}{|c|c|c|c|c|c|c|}
\hline & H 0.036 & & VPI 0.036 & $\Delta$ & H 0.06 & $\times 1$ \\
\hline & $\mathrm{H} \mathrm{O.O}$ & $\bullet$ & WPI 0.072 & & H 0.12 & - $\mathrm{H} 0.24$ \\
\hline & $\begin{array}{ll}(4 & 0.050) \\
(H & 0.072)\end{array}$ & & L inear & & Lnear $\left(\begin{array}{ll}4 \\
\mathrm{H}\end{array}\right.$ & 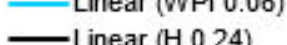 \\
\hline
\end{tabular}

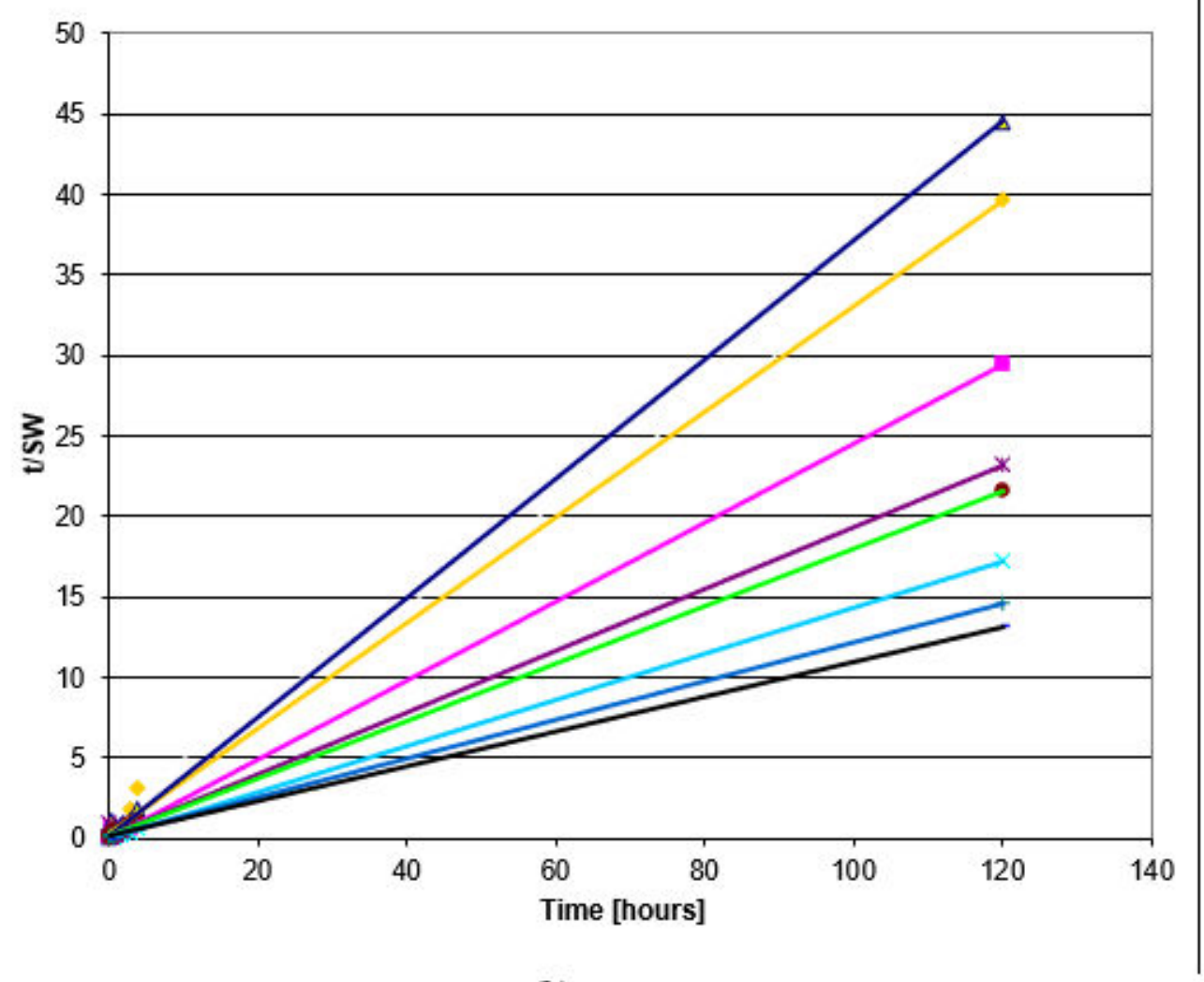

(b)

Figure 6. The plot of $\mathrm{t} / \mathrm{SW}$ against $\mathrm{t}$ for samples $\mathrm{H}$ and WPI (a), and samples containing copper (b). 


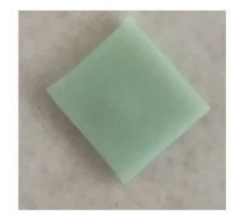

H 0.036

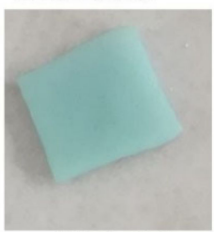

H 0.06

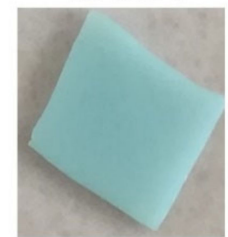

H 0.072

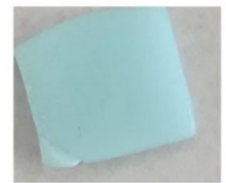

H 0.12

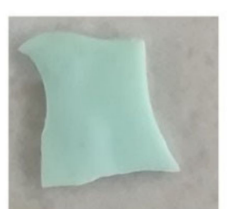

WPI 0.036

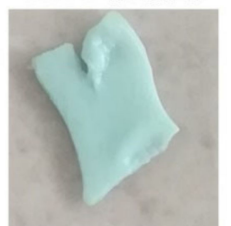

WPI 0.06

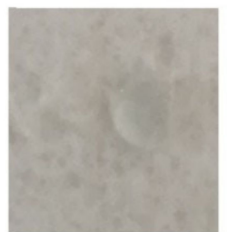

WPI 0.072

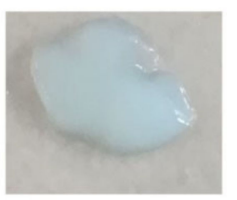

H 0.24

Figure 7. Photographs of hydrogel samples after a week spent in swelling environment.

Future research directions may also be involved in the studies related to the modifications in the secondary structures of proteins following hydrolysis and the synthesis of mixed hydrogels. Obtaining hydrogel composites was also taken into consideration.

\section{Conclusions}

We obtained a new type of hydrogel based on whey protein isolates (WPI), whey protein hydrolysates (WPH), and gelatin crosslinked with $\mathrm{Cu}^{2+}$ ions and plasticized with glycerol by a microwave-assisted method.

Enzymatic hydrolysis using bromelain led to changes in the structure of whey proteins, leading to an increase in the number of functional groups that have been involved in the crosslinking process.

The use of whey protein hydrolysates instead of whey protein isolates resulted in decreasing the swelling degree and increasing the hydrogel's stability.

Increasing copper ion concentrations led to higher hydrogel stability, allowing higher swelling degrees. The best hydrogel samples lasted for one week in swelling medium (water).

The swelling process followed a second order kinetic.

Author Contributions: V.P. conceive the idea, elaborate the methodology, analyzed the data, and drafted the manuscript; V.P. and A.M. conducted the experiments; G.L.P. designed and executed the installation; M.M. and A.M.M. participated to investigations and funding acquisition, P.M.L. revised and edited the manuscript before submission. All authors have read and agreed to the published version of the manuscript.

Funding: This research was funded by ROMANIAN NATIONAL AUTHORITY FOR SCIENTIFIC RESEARCH AND INNOVATION, CNCS-UEFISCDI (http: / / uefiscdi.gov.ro, 20 June 2021) Project PN-III-P2-2.1-BG-2016-0204-112BG, a Bridge Grant: Transfer of knowledge to the economic agent and Project 334 PED/2020 program PN-III-P2-2.1-PED-2019-2953. 
Institutional Review Board Statement: Not applicable.

Informed Consent Statement: Not applicable.

Data Availability Statement: Not applicable.

Acknowledgments: The authors would like to thank Lavinia Nadia Torje for hydrolysis experiments, Danka Dragomir and Mihai Adrian Pop for spelling correction.

Conflicts of Interest: The authors declare no conflict of interest.

\section{References}

1. Sirbu, C.; Cioroianu, T.M.; Cojocaru, I.; Trandafir, V.; Albu, M.G. Fertilizers with Protein Chelated Structures with Biostimulator Role. Rev. Chim 2009, 60, 1135-1140.

2. Chakravartula, S.S.N.; Soccio, M.; Lotti, N.; Balestra, F.; Dalla Rosa, M.; Siracusa, V. Characterization of Composite Edible Films Based on Pectin/Alginate/Whey Protein Concentrate. Materials 2019, 12, 2454. [CrossRef] [PubMed]

3. Osman, A.; Goda, H.A.; Abdel-Hamid, M.; Badran, S.M.; Otte, J. Antibacterial Peptides Generated by Alcalase Hydrolysis of Goat Whey. LWT-Food Sci. Technol. 2016, 65, 480-486. [CrossRef]

4. Cinelli, P.; Schmid, M.; Bugnicourt, E.; Coltelli, M.B.; Lazzeri, A. Recyclability of PET/WPI/PE Multilayer Films by Removal of Whey Protein Isolate-Based Coatings with Enzymatic Detergents. Materials 2016, 9, 473. [CrossRef]

5. Benkerroum, N. Antimicrobial Peptides Generated from Milk Proteins: A Survey and Prospects for Application in the Food Industry. A Review. Int. J. Dairy Technol. 2010, 63, 320-338. [CrossRef]

6. Pena-Ramos, E.; Xiong, Y. Antioxidative Activity of Whey Protein Hydrolysates in a Liposomal System. J. Dairy Sci. 2001, 84, 2577-2583. [CrossRef]

7. Sanabria, J.C.; Urista, C.R.M.; Aguilar, R.E.O.; Illescas, J.; Nava, M. del C.D.; Franco, G.C. Encapsulation of Active Fractions of Whey Proteins with Antioxidant Potential in Pectin-Collagen and Pectin-Gelatin Microparticles. MRS Adv. 2018, 3, 3853-3860. [CrossRef]

8. Tavares, T.; Monteiro, K.; Possenti, A.; Pintado, M.; Carvalho, J.; Malcata, F.X. Antiulcerogenic Activity of Peptide Concentrates Obtained from Hydrolysis of Whey Proteins by Proteases from Cynara Cardunculus. Int. Dairy J. 2011, 21, 934-939. [CrossRef]

9. Gauthier, S.F.; Pouliot, Y.; Saint-Sauveur, D. Immunomodulatory Peptides Obtained by the Enzymatic Hydrolysis of Whey Proteins. Int. Dairy J. 2006, 16, 1315-1323. [CrossRef]

10. Keri Marshall, N.D. Therapeutic Applications of Whey Protein. Altern. Med. Rev. 2004, 9, 136-156.

11. Madureira, A.R.; Tavares, T.; Gomes, A.M.P.; Pintado, M.E.; Malcata, F.X. Invited Review: Physiological Properties of Bioactive Peptides Obtained from Whey Proteins. J. Dairy Sci. 2010, 93, 437-455. [CrossRef] [PubMed]

12. Hernández-Ledesma, B.; Ramos, M.; Gómez-Ruiz, J.Á. Bioactive Components of Ovine and Caprine Cheese Whey. Small Rumin. Res. 2011, 101, 196-204. [CrossRef]

13. Costa, S.M.; Rogero, S.O.; Lugao, A.B. Transdermal Protein Delivery Systems Obtained from the Hydrogels Membrane Matrix. In Proceedings of the World Polymer Congress-Macro 2006, 41st International Symposium on Macromolecules, Rio de Janeiro, Brazil, 16-21 July 2006.

14. Mayorova, O.A.; Jolly, B.C.; Verkhovskii, R.A.; Plastun, V.O.; Sindeeva, O.A.; Douglas, T.E. PH-Sensitive Dairy-Derived Hydrogels with a Prolonged Drug Release Profile for Cancer Treatment. Materials 2021, 14, 749. [CrossRef]

15. Shetty, S.; Hegde, M.N.; Bopanna, T.P. Enamel Remineralization Assessment after Treatment with Three Different Remineralizing Agents Using Surface Microhardness: An in Vitro Study. J. Conserv. Dent. JCD 2014, 17, 49. [CrossRef]

16. Mazilu, A.; Sarosi, C.; Moldovan, M.; Miuta, F.; Prodan, D.; Antoniac, A.; Prejmerean, C.; Dumitrescu, L.S.; Popescu, V.; Raiciu, A.D.; et al. Preparation and Characterization of Natural Bleaching Gels Used in Cosmetic Dentistry. Materials 2019, $12,2106$. [CrossRef]

17. De la Fuente, M.; Hemar, Y.; Singh, H. Influence of k-Carrageenan on the Aggregation Behaviour of Proteins in Heated Whey Protein Isolate Solutions. Food Chem. 2004, 86, 1-9. [CrossRef]

18. Flett, K.L.; Corredig, M. Whey Protein Aggregate Formation during Heating in the Presence of K-Carrageenan. Food Chem. 2009, 115, 1479-1485. [CrossRef]

19. Tan, J.; Joyner, H.S. Characterizing Wear Behaviors of k-Carrageenan and Whey Protein Gels by Numerical Modeling. J. Food Eng. 2018, 235, 98-105. [CrossRef]

20. Lam, R.S.; Nickerson, M.T. The Properties of Whey Protein-Carrageenan Mixtures during the Formation of Electrostatic Coupled Biopolymer and Emulsion Gels. Food Res. Int. 2014, 66, 140-149. [CrossRef]

21. Alavi, F.; Emam-Djomeh, Z.; Yarmand, M.S.; Salami, M.; Momen, S.; Moosavi-Movahedi, A.A. Cold Gelation of Curcumin Loaded Whey Protein Aggregates Mixed with K-Carrageenan: Impact of Gel Microstructure on the Gastrointestinal Fate of Curcumin. Food Hydrocoll. 2018, 85, 267-280. [CrossRef]

22. Chen, L.; Subirade, M. Alginate-Whey Protein Granular Microspheres as Oral Delivery Vehicles for Bioactive Compounds. Biomaterials 2006, 27, 4646-4654. [CrossRef]

23. Déat-Lainé, E.; Hoffart, V.; Garrait, G.; Jarrige, J.-F.; Cardot, J.-M.; Subirade, M.; Beyssac, E. Efficacy of Mucoadhesive Hydrogel Microparticles of Whey Protein and Alginate for Oral Insulin Delivery. Pharm. Res. 2013, 30, 721-734. [CrossRef] [PubMed] 
24. Wichchukit, S.; Oztop, M.; McCarthy, M.; McCarthy, K. Whey Protein/Alginate Beads as Carriers of a Bioactive Component. Food Hydrocoll. 2013, 33, 66-73. [CrossRef]

25. Déat-Lainé, E.; Hoffart, V.; Garrait, G.; Beyssac, E. Whey Protein and Alginate Hydrogel Microparticles for Insulin Intestinal Absorption: Evaluation of Permeability Enhancement Properties on Caco-2 Cells. Int. J. Pharm. 2013, 453, 336-342. [CrossRef] [PubMed]

26. Déat-Lainé, E.; Hoffart, V.; Cardot, J.-M.; Subirade, M.; Beyssac, E. Development and in Vitro Characterization of Insulin Loaded Whey Protein and Alginate Microparticles. Int. J. Pharm. 2012, 439, 136-144. [CrossRef]

27. Ozel, B.; Uguz, S.S.; Kilercioglu, M.; Grunin, L.; Oztop, M.H. Effect of Different Polysaccharides on Swelling of Composite Whey Protein Hydrogels: A Low Field (LF) NMR Relaxometry Study. J. Food Process Eng. 2017, 40, e12465. [CrossRef]

28. Zand-Rajabi, H.; Madadlou, A. Caffeine-Loaded Whey Protein Hydrogels Reinforced with Gellan and Enriched with Calcium Chloride. Int. Dairy J. 2016, 56, 38-44. [CrossRef]

29. Vahedifar, A.; Madadlou, A.; Salami, M. Calcium and Chitosan-Mediated Clustering of Whey Protein Particles for Tuning Their Colloidal Stability and Flow Behaviour. Int. Dairy J. 2017, 73, 136-143. [CrossRef]

30. Kang, N.; Hua, J.; Gao, L.; Zhang, B.; Pang, J. The Interplay between Whey Protein Fibrils with Carbon Nanotubes or Carbon Nano-Onions. Materials 2021, 14, 608. [CrossRef]

31. Chalermthai, B.; Chan, W.Y.; Bastidas-Oyanedel, J.-R.; Taher, H.; Olsen, B.D.; Schmidt, J.E. Preparation and Characterization of Whey Protein-Based Polymers Produced from Residual Dairy Streams. Polymers 2019, 11, 722. [CrossRef]

32. Wang, G.; Liu, N.; Guo, M. Use of Whey Protein as a Natural Polymer for Tissue Adhesive: Preliminary Formulation and Evaluation in Vitro. Polymers 2018, 10, 843. [CrossRef] [PubMed]

33. Egan, T.; Jacquier, J.-C.; Rosenberg, Y.; Rosenberg, M. Cold-Set Whey Protein Microgels for the Stable Immobilization of Lipids. Food Hydrocoll. 2013, 31, 317-324. [CrossRef]

34. Doherty, S.; Gee, V.; Ross, R.; Stanton, C.; Fitzgerald, G.; Brodkorb, A. Development and Characterisation of Whey Protein Micro-Beads as Potential Matrices for Probiotic Protection. Food Hydrocoll. 2011, 25, 1604-1617. [CrossRef]

35. Mohammadian, M.; Madadlou, A. Cold-Set Hydrogels Made of Whey Protein Nanofibrils with Different Divalent Cations. Int. J. Biol. Macromol. 2016, 89, 499-506. [CrossRef] [PubMed]

36. Kuhn, K.R.; Cavallieri, Â.L.F.; Da Cunha, R.L. Cold-set Whey Protein Gels Induced by Calcium or Sodium Salt Addition. Int. J. Food Sci. Technol. 2010, 45, 348-357. [CrossRef]

37. Pereira, R.N.; Rodrigues, R.M.; Altinok, E.; Ramos, Ó.L.; Malcata, F.X.; Maresca, P.; Ferrari, G.; Teixeira, J.A.; Vicente, A.A. Development of Iron-Rich Whey Protein Hydrogels Following Application of Ohmic Heating-Effects of Moderate Electric Fields. Food Res. Int. 2017, 99, 435-443. [CrossRef] [PubMed]

38. Martin, A.; De Jong, G. Enhancing the in Vitro Fe 2+ Bio-Accessibility Using Ascorbate and Cold-Set Whey Protein Gel Particles. Dairy Sci. Technol. 2012, 92, 133-149. [CrossRef] [PubMed]

39. Da Silva, M.V.; Delgado, J.; Goncalves, M. Impact of Mg2+ and Tara Gum Concentrations on Flow and Textural Properties of WPI Solutions and Cold-Set Gels. Int. J. Food Prop. 2010, 13, 972-982. [CrossRef]

40. Farjami, T.; Madadlou, A.; Labbafi, M. Characteristics of the Bulk Hydrogels Made of the Citric Acid Cross-Linked Whey Protein Microgels. Food Hydrocoll. 2015, 50, 159-165. [CrossRef]

41. Zand-Rajabi, H.; Madadlou, A. Citric Acid Cross-Linking of Heat-Set Whey Protein Hydrogel Influences Its Textural Attributes and Caffeine Uptake and Release Behaviour. Int. Dairy J. 2016, 61, 142-147. [CrossRef]

42. Svanberg, L.; Wassén, S.; Gustinelli, G.; Öhgren, C. Design of Microcapsules with Bilberry Seed Oil, Cold-Set Whey Protein Hydrogels and Anthocyanins: Effect of PH and Formulation on Structure Formation Kinetics and Resulting Microstructure during Purification Processing and Storage. Food Chem. 2019, 280, 146-153. [CrossRef] [PubMed]

43. Liu, L.; Li, X.; Zhu, Y.; Bora, A.F.M.; Zhao, Y.; Du, L.; Li, D.; Bi, W. Effect of Microencapsulation with Maillard Reaction Products of Whey Proteins and Isomaltooligosaccharide on the Survival of Lactobacillus Rhamnosus. LWT 2016, 73, 37-43. [CrossRef]

44. Aderibigbe, B.; Ndwabu, S. Evaluation of Whey Protein Isolate-Graft-Carbopol-Polyacrylamide PH-Sensitive Composites for Controlled Release of Pamidronate. Polym. Bull. 2017, 74, 5129-5144. [CrossRef]

45. Mishra, R.; Majeed, A.; Banthia, A. Development and Characterization of Pectin/Gelatin Hydrogel Membranes for Wound Dressing. Int. J. Plast. Technol. 2011, 15, 82-95. [CrossRef]

46. Balakrishnan, B.; Mohanty, M.; Umashankar, P.; Jayakrishnan, A. Evaluation of an in Situ Forming Hydrogel Wound Dressing Based on Oxidized Alginate and Gelatin. Biomaterials 2005, 26, 6335-6342. [CrossRef]

47. Rattanaruengsrikul, V.; Pimpha, N.; Supaphol, P. Development of Gelatin Hydrogel Pads as Antibacterial Wound Dressings. Macromol. Biosci. 2009, 9, 1004-1015. [CrossRef]

48. Wang, T.; Zhu, X.-K.; Xue, X.-T.; Wu, D.-Y. Hydrogel Sheets of Chitosan, Honey and Gelatin as Burn Wound Dressings. Carbohydr. Polym. 2012, 88, 75-83. [CrossRef]

49. Abaee, A.; Mohammadian, M.; Jafari, S.M. Whey and Soy Protein-Based Hydrogels and Nano-Hydrogels as Bioactive Delivery Systems. Trends Food Sci. Technol. 2017, 70, 69-81. [CrossRef]

50. Gunasekaran, S.; Xiao, L.; Ould Eleya, M. Whey Protein Concentrate Hydrogels as Bioactive Carriers. J. Appl. Polym. Sci. 2006, 99, 2470-2476. [CrossRef]

51. Shams, B.; Ebrahimi, N.G.; Khodaiyan, F. Development of Antibacterial Nanocomposite: Whey Protein-Gelatin-Nanoclay Films with Orange Peel Extract and Tripolyphosphate as Potential Food Packaging. Adv. Polym. Technol. 2019, 2019, 1-9. [CrossRef] 
52. Sarbon, N.M.; Badii, F.; Howell, N.K. The Effect of Chicken Skin Gelatin and Whey Protein Interactions on Rheological and Thermal Properties. Food Hydrocoll. 2015, 45, 83-92. [CrossRef]

53. Jiang, Y.; Li, Y.; Chai, Z.; Leng, X. Study of the Physical Properties of Whey Protein Isolate and Gelatin Composite Films. J. Agric. Food Chem. 2010, 58, 5100-5108. [CrossRef] [PubMed]

54. Wang, L.; Auty, M.A.E.; Kerry, J.P. Physical Assessment of Composite Biodegradable Films Manufactured Using Whey Protein Isolate, Gelatin and Sodium Alginate. J. Food Eng. 2010, 96, 199-207. [CrossRef]

55. Jesus, G.L.; Baldasso, C.; Marcílio, N.R.; Tessaro, I.C. Demineralized Whey-Gelatin Composite Films: Effects of Composition on Film Formation, Mechanical, and Physical Properties. J Appl Polym Sci 2020, 137, 49282. [CrossRef]

56. Martin, A.H.; Bakhuizen, E.; Ersch, C.; Urbonaite, V.; de Jongh, H.H.J.; Pouvreau, L. Gelatin Increases the Coarseness of Whey Protein Gels and Impairs Water Exudation from the Mixed Gel at Low Temperatures. Food Hydrocoll. 2016, 56, 236-244. [CrossRef]

57. Tyuftin, A.A.; Wang, L.; Auty, M.A.E.; Kerry, J.P. Development and Assessment of Duplex and Triplex Laminated Edible Films Using Whey Protein Isolate, Gelatin and Sodium Alginate. IJMS 2020, 21, 2486. [CrossRef] [PubMed]

58. Walkenström, P.; Hermansson, A.-M. Fine-Stranded Mixed Gels of Whey Proteins and Gelatin. Food Hydrocoll. 1996, 10, 51-62. [CrossRef]

59. Fitzsimons, S.M.; Mulvihill, D.M.; Morris, E.R. Segregative Interactions between Gelatin and Polymerised Whey Protein. Food Hydrocoll. 2008, 22, 485-491. [CrossRef]

60. Laranjo, M.R.; Costa, B. de S.; Garcia-Rojas, E.E. Stabilization of Gelatin and Carboxymethylcellulose Water-in-Water Emulsion by Addition of Whey Protein. Polímeros 2019, 29, e2019051. [CrossRef]

61. Zúñiga, R.N.; Kulozik, U.; Aguilera, J.M. Ultrasonic Generation of Aerated Gelatin Gels Stabilized by Whey Protein $\beta$ Lactoglobulin. Food Hydrocoll. 2011, 25, 958-967. [CrossRef]

62. Da Lira, K.H.D.S.; Passos, T.S.; Ramalho, H.M.M.; da Rodrigues, K.D.S.R.; de Vieira, É.A.; de Cordeiro, A.M.T.M.; de Maciel, B.L.L.; da Damasceno, K.S.F.S.C.; de Sousa, F.C., Jr.; de Assis, C.F. Whey Protein Isolate-Gelatin Nanoparticles Enable the Water-Dispersibility and Potentialize the Antioxidant Activity of Quinoa Oil (Chenopodium Quinoa). PLoS ONE 2020, 15, $\mathrm{e} 0240889$.

63. Dziadek, M.; Kudlackova, R.; Zima, A.; Slosarczyk, A.; Ziabka, M.; Jelen, P.; Shkarina, S.; Cecilia, A.; Zuber, M.; Baumbach, T.; et al. Novel Multicomponent Organic-Inorganic WPI/Gelatin/CaP Hydrogel Composites for Bone Tissue Engineering. J Biomed Mater Res 2019, 107, 2479-2491. [CrossRef]

64. Stănilă, A.; Braicu, C.; Stănilă, S. Antibacterial Activity of Copper and Cobalt Amino Acids Complexes. Not. Bot. Horti Agrobot. Cluj-Napoca 2011, 39, 124-129. [CrossRef]

65. Amolegbe, S.A.; Adewuyi, S.; Akinremi, C.A.; Adediji, J.F.; Lawal, A.; Atayese, A.O.; Obaleye, J.A. Iron (III) and Copper (II) Complexes Bearing 8-Quinolinol with Amino-Acids Mixed Ligands: Synthesis, Characterization and Antibacterial Investigation. Arab. J. Chem. 2015, 8, 742-747. [CrossRef]

66. Rani, V.S.V.; Prabakaran, E.; Jesudurai, D. Synthesis, Characterization and Antimicrobial Activity of L-Tryptophan Coordinated Copper (II) N, N-Donor Amino Acid Complexes. Asian J. Chem. 2016, 28, 2685. [CrossRef]

67. Tao, B.; Lin, C.; Deng, Y.; Yuan, Z.; Shen, X.; Chen, M.; He, Y.; Peng, Z.; Hu, Y.; Cai, K. Copper-Nanoparticle-Embedded Hydrogel for Killing Bacteria and Promoting Wound Healing with Photothermal Therapy. J. Mater. Chem. B 2019, 7, 2534-2548. [CrossRef] [PubMed]

68. Mokhtar, A.; Djelad, A.; Bengueddach, A.; Sassi, M. CuNPs-Magadiite/Chitosan Nanocomposite Beads as Advanced Antibacterial Agent: Synthetic Path and Characterization. Int. J. Biol. Macromol. 2018, 118, 2149-2155. [CrossRef]

69. Forero, J.C.; Roa, E.; Reyes, J.G.; Acevedo, C.; Osses, N. Development of Useful Biomaterial for Bone Tissue Engineering by Incorporating Nano-Copper-Zinc Alloy (NCuZn) in Chitosan/Gelatin/Nano-Hydroxyapatite (Ch/G/NHAp) Scaffold. Materials 2017, 10, 1177. [CrossRef]

70. Prodan, D.; Filip, M.; Perhaița, I.; Vlassa, M.; Popescu, V.; Marcus, I.; Moldovan, M. The Influence of Minerals and Lactose Content on the Stability of Whey Protein Powders. Studia Univ. Babes-Bolyai Chem. 2017, 62, 397-410. [CrossRef]

71. Fernández, A.; Kelly, P. PH-Stat vs. Free-Fall PH Techniques in the Enzymatic Hydrolysis of Whey Proteins. Food Chem. 2016, 199, 409-415. [CrossRef]

72. Adler-Nissen, J. Enzymic Hydrolysis of Food Proteins.; Elsevier: Amsterdam, The Netherlands, 1986; ISBN 0-85334-386-1.

73. Yin, Y.; Ji, X.; Dong, H.; Ying, Y.; Zheng, H. Study of the Swelling Dynamics with Overshooting Effect of Hydrogels Based on Sodium Alginate-g-Acrylic Acid. Carbohydr. Polym. 2008, 71, 682-689. [CrossRef]

74. Poulsen, N.A.; Eskildsen, C.E.; Akkerman, M.; Johansen, L.B.; Hansen, M.S.; Hansen, P.W.; Skov, T.; Larsen, L.B. Predicting Hydrolysis of Whey Protein by Mid-Infrared Spectroscopy. Int. Dairy J. 2016, 61, 44-50. [CrossRef]

75. Mohammadian, M.; Madadlou, A. Characterization of Fibrillated Antioxidant Whey Protein Hydrolysate and Comparison with Fibrillated Protein Solution. Food Hydrocoll. 2016, 52, 221-230. [CrossRef]

76. Gherman, T.; Popescu, V.; Carpa, R.; Rapa, M.; Gavril, G.L.; Dudescu, M.C.; Bombos, D. Potential Use of Galium Verum Essential Oil for Antibacterial Properties in Gelatin Based Hydrogels Prepared by Microwave Irradiation Technique. Rev. De Chim. 2018, 69, 575-580. [CrossRef]

77. Lee, S.-H.; Lefèvre, T.; Subirade, M.; Paquin, P. Changes and Roles of Secondary Structures of Whey Protein for the Formation of Protein Membrane at Soy Oil/Water Interface under High-Pressure Homogenization. J. Agric. Food Chem. 2007, 55, 10924-10931. [CrossRef] [PubMed] 
78. Dascalu (Rusu), L.M.; Moldovan, M.; Prodan, D.; Ciotlaus, I.; Popescu, V.; Baldea, I.; Carpa, R.; Sava, S.; Chifor, R.; Badea, M.E. Assessment and Characterization of Some New Photosensitizers for Antimicrobial Photodynamic Therapy (APDT). Materials 2020, 13, 3012. [CrossRef] [PubMed]

79. Cai, S.; Singh, B.R. A Distinct Utility of the Amide III Infrared Band for Secondary Structure Estimation of Aqueous Protein Solutions Using Partial Least Squares Methods. Biochemistry 2004, 43, 2541-2549. [CrossRef]

80. Singh, B.R.; DeOliveira, D.B.; Fu, F.-N.; Fuller, M.P. Fourier Transform Infrared Analysis of Amide III Bands of Proteins for the Secondary Structure Estimation; International Society for Optics and Photonics: Bellingham, WA, USA, 1993; Volume 1890, pp. 47-55.

81. Demchenko, A.P. Ultraviolet Spectroscopy of Proteins; Springer Science \& Business Media: Berlin, Germany, 2013; ISBN 3-642-708471.

82. Gunasekaran, S.; Ko, S.; Xiao, L. Use of Whey Proteins for Encapsulation and Controlled Delivery Applications. J. Food Eng. 2007, 83, 31-40. [CrossRef]

83. Xu, S.; Fan, L.; Zeng, M.; Wang, J.; Liu, Q. Swelling Properties and Kinetics of CaCl2/Polyacrylamide Hygroscopic Hybrid Hydrogels. Colloids Surf. A: Physicochem. Eng. Asp. 2010, 371, 59-63. [CrossRef] 